\title{
FOCO
}

\section{Avaliadores Ad Hoc n⿳20}

Agradecemos imensamente a contribuição dos seguintes avaliadores:

Liana Johann

Marivone Zabott

Danilo Martins

Patricia Barbosa

Cláudia Battestin

Maisa Cardoso

Matheus Alpes

Loriane Trombini Frick 